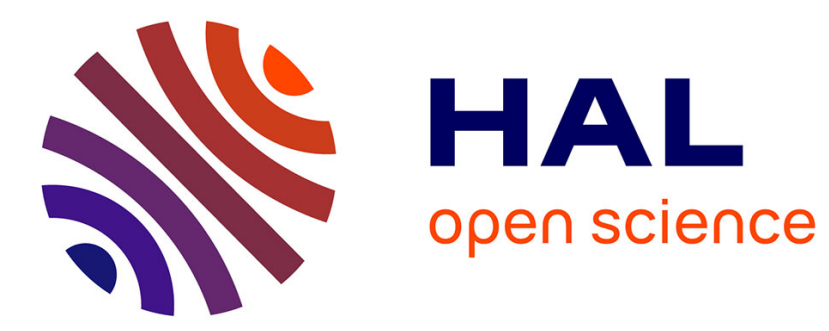

\title{
Effect of salinity and calcium on tomato fruit proteome
} Arafet Manaa, Mireille Faurobert, Benoit B. Valot, Jean-Paul Bouchet, Dominique Grasselly, Mathilde M. Causse, Hela Ben Ahmed

\section{To cite this version:}

Arafet Manaa, Mireille Faurobert, Benoit B. Valot, Jean-Paul Bouchet, Dominique Grasselly, et al.. Effect of salinity and calcium on tomato fruit proteome. OMICS, 2013, 17 (6), 15 p. 10.1089/omi.2012.0108 . hal-02648418

\section{HAL Id: hal-02648418 \\ https://hal.inrae.fr/hal-02648418}

Submitted on 29 May 2020

HAL is a multi-disciplinary open access archive for the deposit and dissemination of scientific research documents, whether they are published or not. The documents may come from teaching and research institutions in France or abroad, or from public or private research centers.
L'archive ouverte pluridisciplinaire HAL, est destinée au dépôt et à la diffusion de documents scientifiques de niveau recherche, publiés ou non, émanant des établissements d'enseignement et de recherche français ou étrangers, des laboratoires publics ou privés. 


\title{
Effect of Salinity and Calcium on Tomato Fruit Proteome
}

\author{
Arafet Manaa, Mireille Faurobert, ${ }^{2}$ Benoît Valot, ${ }^{3}$ Jean-Paul Bouchet, ${ }^{2}$ Dominique Grasselly, \\ Mathilde Causse, ${ }^{2}$ and Hela Ben Ahmed ${ }^{1}$
}

\begin{abstract}
Salinity is a major abiotic stress that adversely affects plant growth and productivity. The physiology of the tomato in salty and nonsalty conditions has been extensively studied, providing an invaluable base to understand the responses of the plants to cultural practices. However few data are yet available at the proteomic level looking for the physiological basis of fruit development, under salt stress. Here, we report the effects of salinity and calcium on fruit proteome variations of two tomato genotypes (Cervil and Levovil). Tomato plants were irrigated with a control solution $\left(3 \mathrm{dSm}^{-1}\right)$ or with saline solutions $\left(\mathrm{Na}\right.$ or $\mathrm{Ca}+\mathrm{Na}$ at $\left.7.6 \mathrm{dSm}^{-1}\right)$. Tomato fruits were harvested at two ripening stages: green (14 days post-anthesis) and red ripe. Total proteins were extracted from pericarp tissue and separated by two-dimensional gel electrophoresis. Among the 600 protein spots reproducibly detected, 53 spots exhibited significant abundance variations between samples and were submitted to mass spectrometry for identification. Most of the identified proteins were involved in carbon and energy metabolism, salt stress, oxidative stress, and proteins associated with ripening process. Overall, there was a large variation on proteins abundance between the two genotypes that can be correlated to salt treatment or/and fruit ripening stage. The results showed a protective effect of calcium that limited the impact of salinization on metabolism, ripening process, and induced plant salt tolerance. Collectively, this work has improved our knowledge about salt and calcium effect on tomato fruit proteome.
\end{abstract}

\section{Introduction}

$\mathbf{T}$ OMATo (Solanum lycopersicum) is ranked among the important vegetables in the economic sphere. Tomato is advocated as a model crop to investigate plant physiology, genetics, and fruit ripening, leading to substantial information regarding the biology of this economically important fruit (Faurobert et al., 2007). On the other hand, to face the decrease in water resources in the countries around the Mediterranean, irrigation of a tomato crop with salinized water could provide a convenient solution (D'Amico et al., 2003; Incerti et al., 2007).

High salt concentrations improved tomato fruit quality with low impact on the commercial yield (Adams, 1991; De Pascale et al., 2001; Dorais et al., 2001; Gautier et al., 2009). The combination of all these features has led us to consider tomato as a main target for proteomic studies. Thus, transcriptomic and proteomic technologies were used as a guide to scrutinize tomato fruits with regard to environmental conditions during growth and harvest, including the ripening stage, as it is stipulated in international guidance documents for the nutritional and toxicological assessment of genetically modified plants (Kok et al., 2008). In fact, comparative proteomics has been successfully applied for systematic scrutiny of proteins in several plant species under a wide range of abiotic challenges, including salt stress (Manaa et al., 2011; Sobhanian et al., 2010; Zhang et al., 2012), drought (Alvarez et al., 2008; Mohammadi et al., 2012; Salekdeh et al., 2002), high or low temperature (Gao et al., 2009; Zou et al., 2011), ultraviolet radiation (Kaspar et al., 2010), heavy metals (Ahsan et al., 2009), and herbicides (Holmes et al., 2006).

In addition, many studies of the development and maturation of tomato fruits have resulted in the identification of specific genes that participate in ripening (Chung et al., 2010; Giovannoni, 2007; Karlova et al., 2011). Similarly, much has been learned about the substantial changes in both primary and secondary metabolism that accompanies tomato fruit

\footnotetext{
${ }^{1}$ Unité d'Ecophysiologie et Nutrition des Plantes, Département de Biologie, Faculté des Sciences de Tunis, Université Tunis El Manar, Tunisie.

${ }^{2}$ Institut National de la Recherche Agronomique, Unité de Génétique et Amélioration des Fruits et Légumes, Domaine Saint-Maurice, Montfavet Cedex, France.

${ }^{3}$ Institut National de la Recherche Agronomique, Unité de Recherches en Génétique Végétale, Gif sur Yvette, France.

${ }^{4}$ Ctifl (Centre Technique Interprofessionnel des Fruits et Légumes), Centre Ctifl de Saint-Rémy-de-Provence, Saint Rémy de Provence, France.
} 
Table 1. Content in Macro-elements (mM) of the Three Different Nutrient Solutions Delivered to the Plant

\begin{tabular}{lcccccccccccccc}
\hline & $C E d S . c m$ & $N(N O 3)$ & $N(N H 4)$ & $S(S O 4)$ & $C l$ & $P$ & $K$ & $C a$ & $M g$ & $N a$ & $K / C a+M g$ & $K / C a$ & $M g / C a$ & $K / M g$ \\
\hline Control & 3 & 13.8 & 0 & 2.9 & 4.1 & 1.6 & 9.7 & 5.5 & 2.3 & 0.7 & 0.62 & 0.87 & 0,42 & 2.10 \\
$\mathrm{Na}$ & 7.6 & & & & 45 & & & & & \\
$\mathrm{Na}+\mathrm{Ca}$ & 7.6 & 24.3 & 0 & 7.3 & 25.2 & 1.6 & 14.1 & 28.8 & 2.9 & 17.5 & 0.41 & 0.49 & 0.20 & 2.41 \\
\hline
\end{tabular}

From Gautier et al., 2009.

ripening, though much of this data has not been directly related to regulatory events (Carrari and Fernie, 2006) and often target specific pathways. On a more comprehensive scale, tomato development has also been examined, but only limited results are available with respect to genotype, developmental stage, or number of measured parameters. The tomato fruit proteome variations have also been investigated. It was found that protein spots associated with energy and carbon metabolism or with oxidative stress showed an increase in intensity during fruit development with maximal abundance in red ripe fruits (Faurobert et al., 2007). In some cases, these investigations either boosted or confirmed previous data on genes/proteins whose expression changed during fruit development and maturation (Carrari et al., 2006; Fei et al., 2004; Lemaire-Chamley et al., 2005).

Several studies look at plant response to abiotic stress factors at the proteome level and could contribute to better understanding of physiological mechanisms underlying plant stress response: perception of stress, signaling events leading to changes in gene expression, changes at transcript, protein, as well as metabolite levels, underlying plant acclimation to a given stress and an acquisition of an enhanced plant stress tolerance (Kosová et al., 2011; Zhang et al., 2012). However, few data are yet available about fruit development proteomics with respect to salt stress responses of the tomato plant.

One approach to minimize the effects of salinity on plants consists in substrate nutrient enrichment (as N, P, K, Mg, and Ca) in order to reduce $\mathrm{Na}^{+}$and $\mathrm{Cl}^{-}$injuries in plants (Kaya et al., 2003; Plieth, 2005; Song and Roe, 2008). Ca is an essential element in all plants. Serving as an important second messenger (Bush, 1995), the calcium ion has unique properties and universal ability to transmit diverse signals that trigger primary physiological actions in cells in response to hormones, pathogens, light, gravity, and stress factors (Malhó et al., 2006; Trewavas and Malhó, 1998). Sufficient calcium concentration is required at all stages of plant growth and development, playing a fundamental role in regulating polar growth of cells and tissues and participating in plant adaptation to various stress factors (Song and Roe, 2008). In fact, exogenous $\mathrm{Ca}^{2+}$ can enhance plant drought resistance, inhibit the synthesis of activating oxides, protect the structure of cellular plasma membranes, and maintain normal photosynthesis, as well as regulate the metabolism of plant hormone and other important chemicals (Song and Roe, 2008). Numerous data suggest that $\mathrm{Na}^{+}$ions compete with $\mathrm{Ca}^{2+}$ ions for binding sites under salinity conditions and that apoplastic $\mathrm{Ca}^{2+}$ directly alleviates symptoms produced by mineral toxicities. $\mathrm{Ca}^{2+}$ also helps to establish a favorable $\mathrm{K}^{+}: \mathrm{Na}^{+}$ ratio under salt stress (Kaya et al., 2003; Plieth, 2005; Ehret et al., 1990).

This analysis provides a view of the proteome level changes, in tomato fruit, elicited by $\mathrm{NaCl}$ exposure $(\mathrm{Na}$ or $\mathrm{Ca}+\mathrm{Na})$ and links the protein variations with fruit development stage on the basis of their function and their repercussion on salt stress response. The present work also gives a new report about moderate effects of calcium, at the proteomic level, on tomato fruit cultivated under salt stress. As a whole, this study provides the framework for the better understanding of the mechanisms that govern plant responses to $\mathrm{NaCl}$-induced stress.

\section{Methods \\ Plant material, salinity treatments, and growth conditions}

Two contrasting sized genotypes of tomato (Solanum lycopersicum, production Vilmorin ${ }^{\circledR}$, France) were used: a cherry tomato cerasiforme (cv. Cervil) and a medium-sized tomato (cv. Levovil). Tomato plants were cultivated in a greenhouse in a full randomized trial at the Ctifl Research Station, Bellegarde, Southern France. The adopted culture protocol was performed as previously described (Gautier et al., 2009). Control plants were irrigated with the $3 \mathrm{dS} \mathrm{cm}^{-1}$ solution (Table 1). For other plants, the solution conductivity was increased to $7.6 \mathrm{dS} \mathrm{cm}^{-1}$ either by adding $\mathrm{NaCl}$ only: $40.8 \mathrm{mM}$ $\mathrm{Na}$ (Na treatment) or by a combination of $\mathrm{NaCl}$ plus $\mathrm{CaCl}_{2}$ : $16.4 \mathrm{mM} \mathrm{Na}, 8.9 \mathrm{mM} \mathrm{Ca}(\mathrm{Ca}+\mathrm{Na}$ treatment). The solutions were supplied using a drip irrigation system in order to maintain at least $10 \%$ drainage. All plant side shoots were removed as they appeared and the old leaves were removed every 15 days. Fruit load was set at 5 and 20 fruits truss $^{-1}$ in Levovil and Cervil, respectively. The mean air temperature varied from $18.7^{\circ} \mathrm{C}$ in January to $21.7^{\circ} \mathrm{C}$ in June, with a relative humidity varying from $83 \%$ to $72 \%$.

Flowers were tagged at anthesis and tomato fruits were harvested to obtain for each genotype and treatment the two following ripening stages: green (14 days post-anthesis DPA) and red ripe (RR). Fruit ripening stages were defined from fruit external coloration in agreement with Jiménez et al. (2002): the green stage (with white distal end, fully developed green fruits, usually 2-4 days before breaker stage) and the red ripe stage defined as the pink stage plus 5 days. For each genotype, four subsamples of 10 fruits were harvested per treatment and per developmental stage. After harvest, fruits were weighed and pericarp tissues were frozen in liquid nitrogen and maintained at $-80^{\circ} \mathrm{C}$ until it was ground in liquid nitrogen. Means ( \pm standard error) corresponded to the average of four independent samplings, extractions, and analyses.

\section{Proteomic methods}

Total protein extraction and quantification were conducted according to previous methods (Faurobert et al., 
2006). All procedures of two-dimensional polyacrylamide gel electrophoresis, gel staining, imaging, data analysis, and protein identification were performed as described in our previous work (Manaa et al., 2011). Briefly, before twodimensional electrophoresis, protein concentration was determined using the Bradford assay (Ramagli and Rodriguez, 1985) with bovine serum albumin (BSA) as a standard. $500 \mu \mathrm{g}$ of total proteins were separated in the first dimension (IEF; isoelectric focusing) on immobilized dry strip gels, $\mathrm{pH} 4-7 / 24 \mathrm{~cm}$ (Amersham Bioscience, Uppsala, Sweden). The separation of proteins in the second dimension was performed with SDS polyacrylamide gels (11\%). The SDS-PAGE gels were stained with Coomassie brilliant blue (CBB). Imaging and data analysis were performed using Progenesis SameSpots v3.0 software. The protein spots were identified by nano LC-MS/MS. The identified protein spots were grouped according to functional categories "MIPS Functional Catalogue" (http://mips.gsf.de/ proj/funcatDB) and according to the literature.

\section{Statistical analysis}

Progenesis SameSpots v3.0 software was used to detect varying spots using one way ANOVA on normalized spot volume from the four gel repeats. To detect treatment, genotype, and interaction effects, a two-way analysis of variance (ANOVA) was performed using 'Statistica' software (version 6.0). A $p$ value less than 0.05 was considered statistically significant.

\section{Results and Discussion}

\section{Comparative analysis of fruit pericarp proteome at ripening stages}

Proteomic characterization of tomato fruits, from Cervil and Levovil genotypes, was achieved by 2-DE analysis of proteins extracted from the pericarp at two development stages; mature green (14 DPA) and red ripe (RR). A 2-DE gel, of the Cervil genotype at red ripe stage, is considered as the reference gel (Fig. 1).

Statistical analysis $(p<0.05)$ revealed 53 protein spots differentially expressed among genotypes, treatments, and fruit development stages. These spots were excised from the gels, digested, and subjected to MS analysis to determine protein identity. We identified corresponding protein sequences for 52 out of the 53 protein spots (Table 2). For the remaining spot (FC43), it was not possible to determine the protein spot identity because of a lack of matching unigene sequences. All identified proteins in this study have enriched the proteomic database of the tomato fruit SOLstIS developed at INRA Avignon (http://w3.avignon.inra.fr/solstis/).

Some proteins were identified in more than one spot, although they were excised from the same gel, for example, glycine-rich protein (spots 40 and 41), nascent polypeptide associated complex alpha chain protein (spots 35 and 36), and lactoylglutathione lyase (spots 18 and 20). Further examination of 2-DE gel patterns indicated that the inferred mass or isoelectric point values of these spots differed, due perhaps to post-translational modifications (glycosylation or phosphorylation) or degradation,

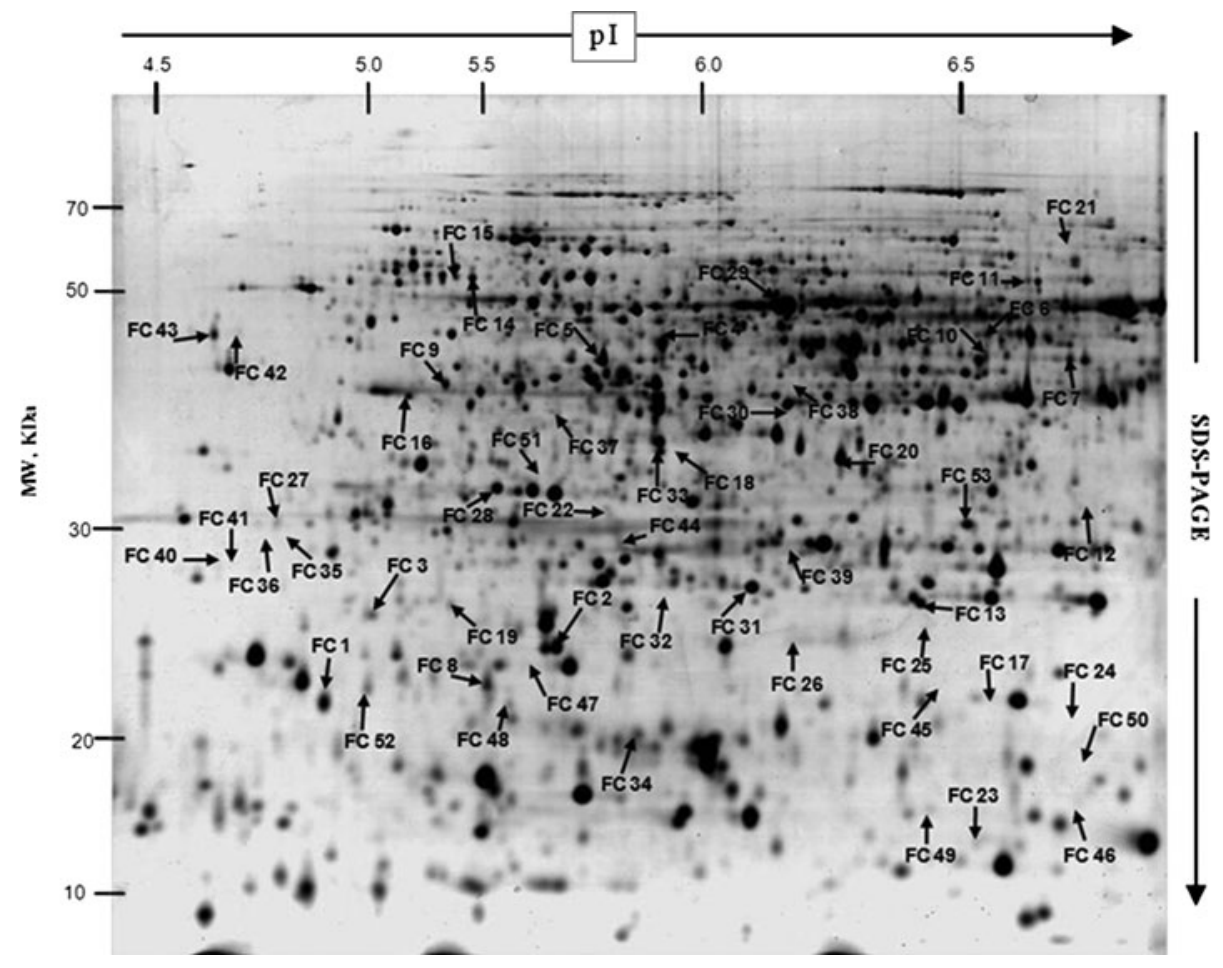

FIG. 1. Representative two-dimensional electrophoresis gel of tomato fruit proteins of Cervil, in control growth conditions at red ripe stage. The positions and numbers of the 53 identified protein spots are indicated by arrows. Identified spots are annotated in the gel by the number that appears in Table 2. Spots that were detected only at other stages and treatment than RR are not visible on this gel. 


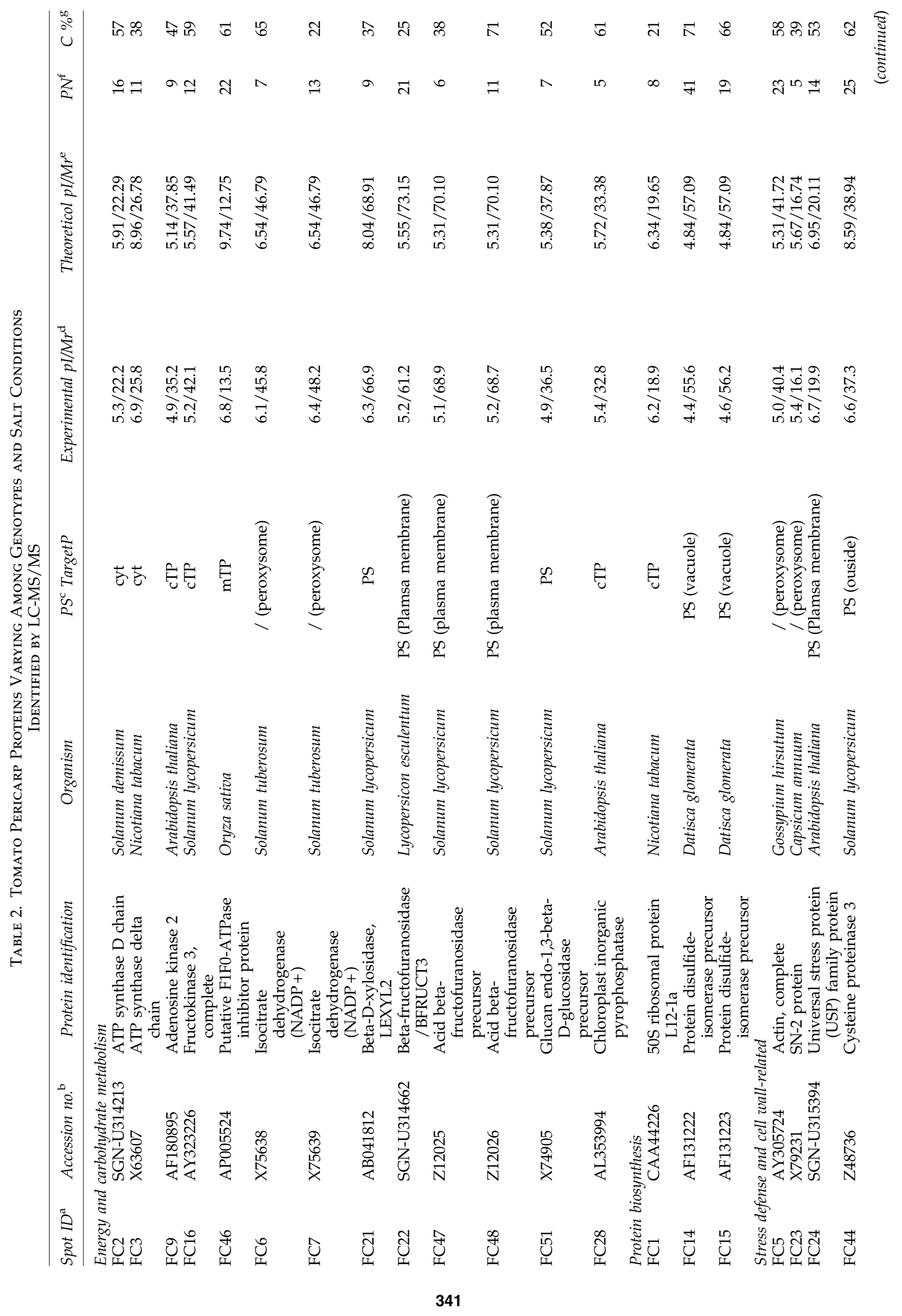




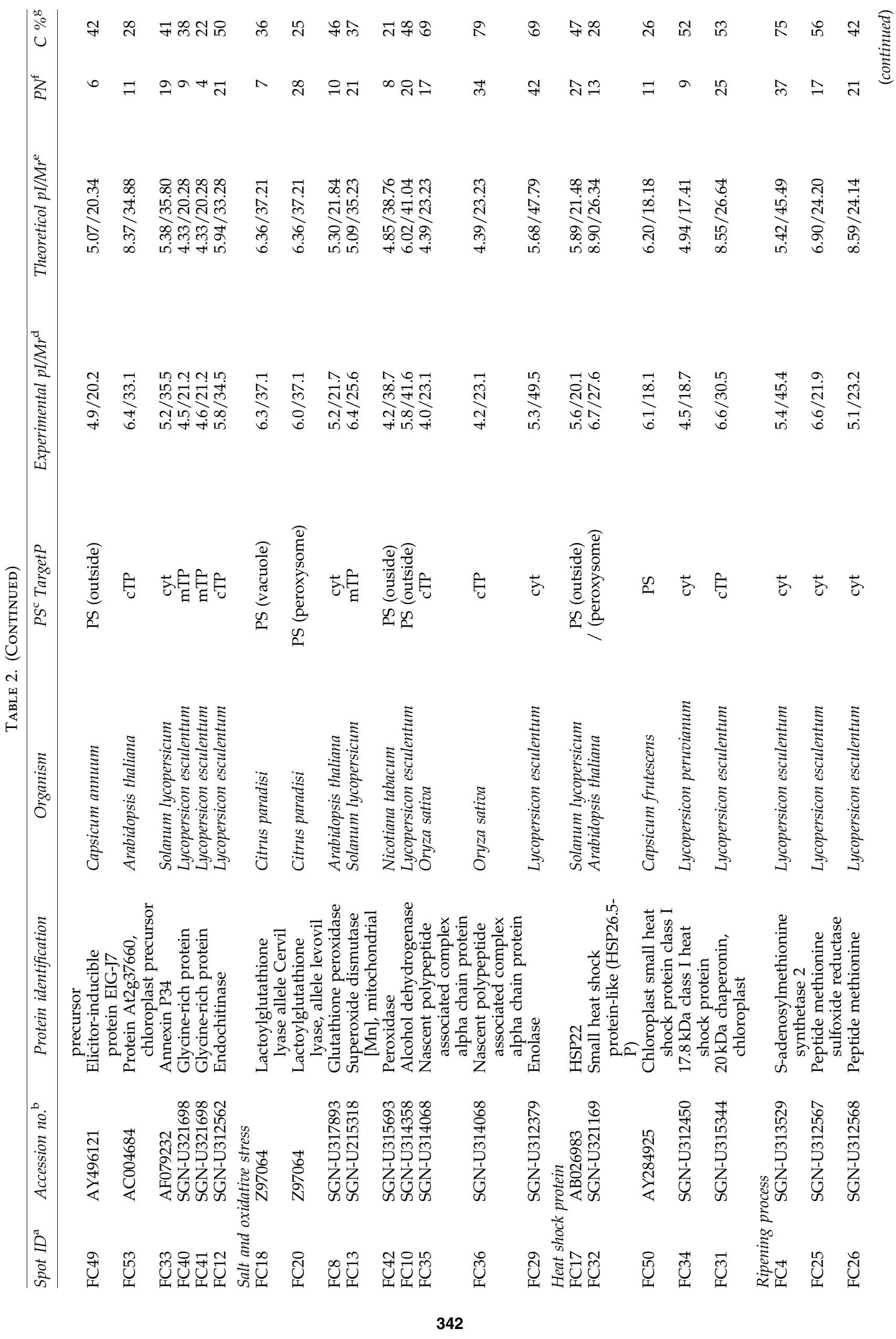




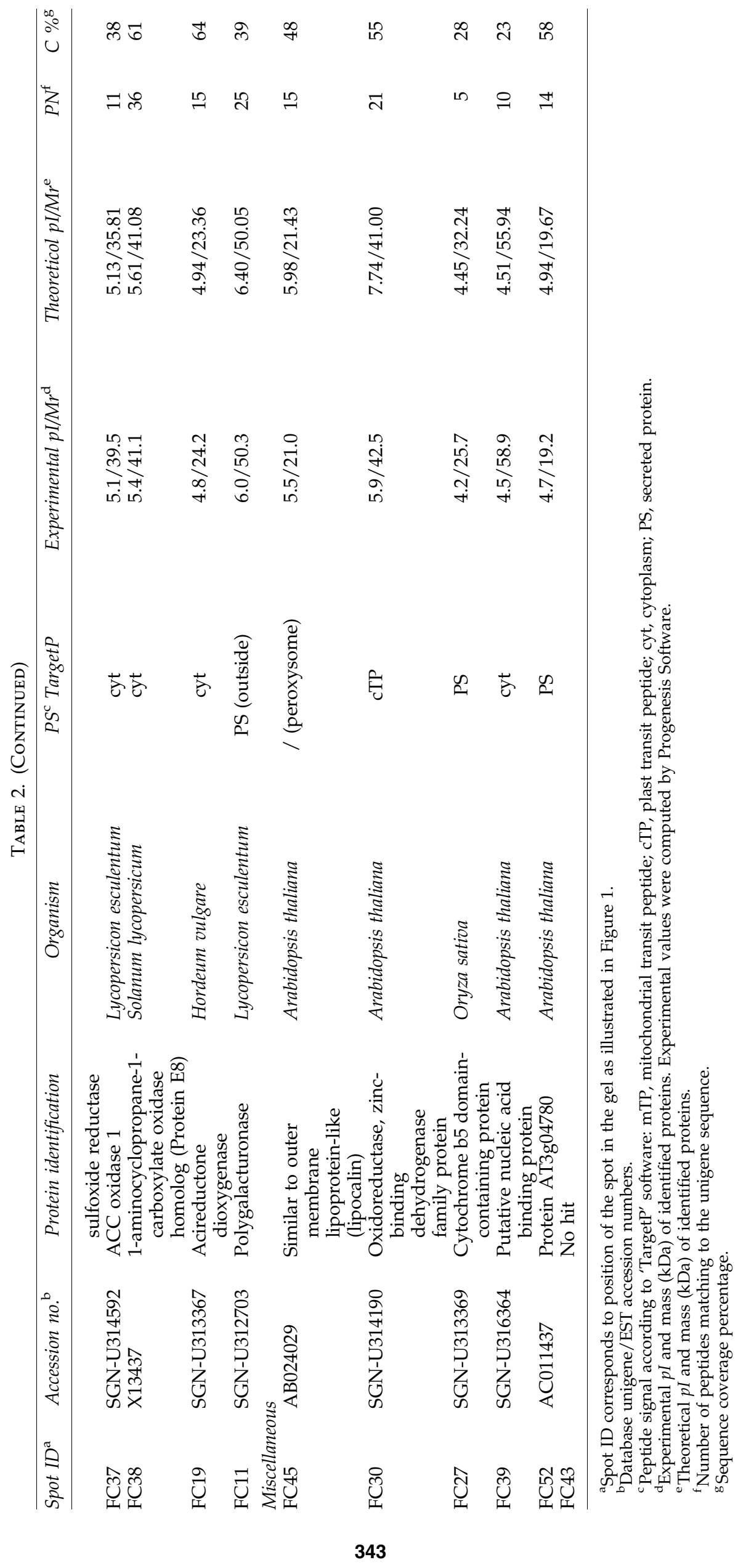




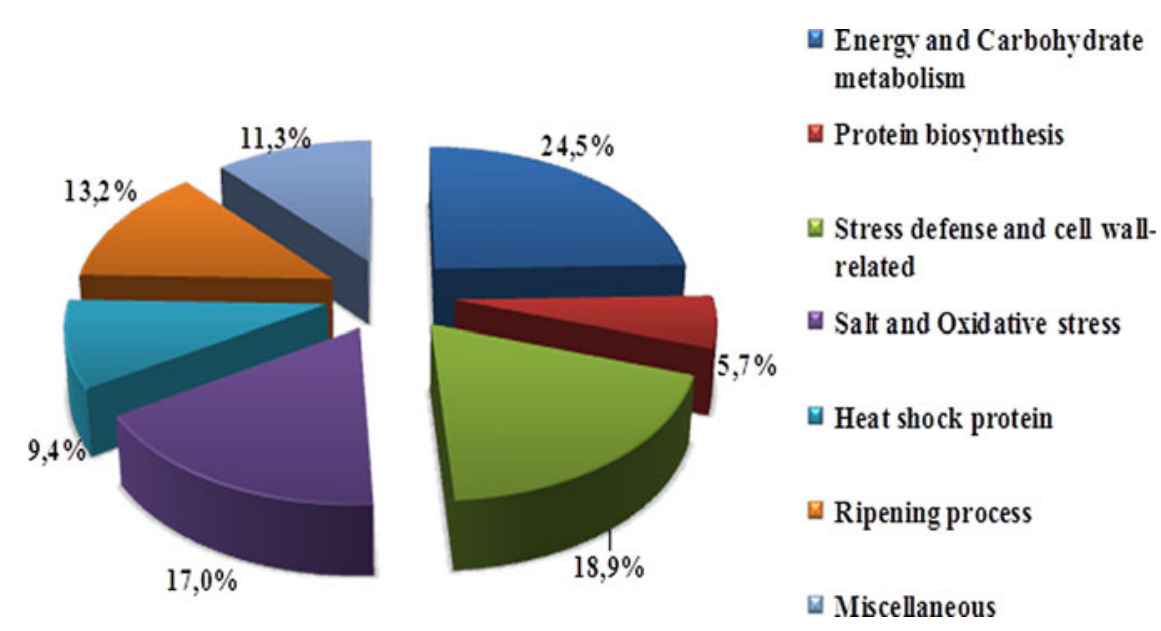

FIG. 2. Distribution of identified proteins into functional categories.

which can change the $\mathrm{pI}$ and $M r$ of proteins (Rossignol et al., 2006).

Distribution of tomato protein spots into putative functional categories is represented in Figure 2. The identified proteins were classified into seven following functional categories including energy and carbon metabolism (13 spots), protein biosynthesis (3 spots), stress defense and cell wall-related (10 spots), salt and oxidative stress (9 spots), heat shock protein ( 5 spots), ripening process ( 7 spots), and miscellaneous (6 spots). The majority of proteins that were characterized exhibited significant variation during the two ripening steps (mature green and red ripe) and were differentially expressed among genotypes under salt treatment.

This analysis allowed a comparison of the protein repertoire in two analyzed genotypes, determining quantitative variations in each genotype during ripening. Representative gels are shown in Supplementary Figure S1 (supplementary material is available online at www.liebertonline.com/omi). The majority of proteins that were characterized are known to be regulated during tomato fruit development (Supplementary Table S1 and Table 3.). About 8 proteins (spots 3, 20, 30, $33,37,39,52$, and 53) remained stable between 14 DPA and the RR stage. However, 11 proteins, whose maximal quantity was detected at the 14 DPA stage, further decreased during the RR stage (spots 1, 2, 4, 6, 8, 9, 14, 15, 28, 29, and 31). Nevertheless, lasting proteins ( 34 spots) showed their lowest level of abundance at 14 DPA stage and increased at the RR stage.

On the other hand, among all these spots, four proteins (spots 27, 36, 43, and 51) showed variation linked to development stage and genotype factor at the same time. Two of them (spots 27 and 36) exhibited an increase in intensity, in Levovil genotype at RR stage and the two other (spots 43 and 51) were increased in Cervil genotype during $R R$ stage as compared to the green stage.

Functional characterization of identified proteins showed that a major part of the spots related to carbon compounds and carbohydrate metabolism (isocitrate dehydrogenase, fructokinase $3, \beta$-D-xylosidase, acid $\beta$-fructofuranosidase, glucan endo-1,3- $\beta$-D-glucosidase) or oxidative processes (superoxide dismutase, peroxidase, alcohol dehydrogenase, peptide methionine sulfoxide reductase, lactoylglutathione lyase) increased during fruit development whatever the genotype. An increase in spot intensity of these proteins was observed during fruit development with maximal abundance in red ripe fruits. In contrast, quantitative analysis indicated that spots linked to amino acid metabolism and protein synthesis (S-adenosylmethionine synthetase 2, 50S ribosomal protein L, protein disulfide-isomerase) were mainly decreased at the RR stage compared to mature green stage in both genotypes. The obtained results confirmed previous data regarding the proteins expression variation during the development and maturation of fruits (Carrari et al., 2006; Faurobert et al., 2007; Kosová et al., 2011; Lemaire-Chamley et al., 2005).

Other interesting proteins in terms of ripening process are polygalacturonase (spot 11) and ACC oxidase (spot 37) which were highly upregulated in RR compared to mature green fruit stage in both genotypes. In tomato, polygalacturonase was thoroughly studied as a key mediator of fruit softening (Fei et al., 2004). Nevertheless, transgenic tomato plants with suppressed polygalacturonase expression showed no effects on fruit softening (Smith et al., 1990). Concerning ACC oxidase, it is a key enzyme for ethylene production, whose levels in climacteric fruits precede the onset of ripening (AdamsPhillips et al., 2004; Giovannoni, 2004).

Our study picked out four HSP (spots 17, 32, 34, and 50) and one chaperone (spot 31) which were increased at RR stage in both genotypes. Although they were first described as induced by various stress treatments as salinity (Jiang et al., 2007; Manaa et al., 2011), drought (Mohammadi et al., 2012), cold stress (Page et al., 2010), hypoxia and anoxia (Kosová et al., 2011), and waterlogging (Ahsan et al., 2007), HSPs are overexpressed under several types of stress and also during plant development and fruit ripening (Faurobert et al., 2007; Rocco et al., 2006). In previous studies, it has been demonstrated that HSPs play roles in facilitating fruit ripening by protecting cellular machinery against heat stress during the daytime rise in field temperature (Ramakrishna et al., 2003). HSPs, which were originally thought to be protective factors induced specifically by heat stress, were also found to be developmentally regulated in the absence of stress (Vierling, 1991). 
Table 3. Change in Protein Relative Abundance under Salt Treatments (Salt Effect) and during Transition from Mature Green to RR Stage (Fruit Stage Effect)

\begin{tabular}{|c|c|c|c|c|c|c|c|c|c|c|c|}
\hline \multirow[b]{4}{*}{ Spot ID } & \multirow[b]{4}{*}{ Protein identification } & \multicolumn{8}{|c|}{ Salt effect (compared to control) } & \multirow{3}{*}{\multicolumn{2}{|c|}{$\begin{array}{l}\text { Fruit stage effect } \\
\text { (transition from mature } \\
\text { green to RR stage) }\end{array}$}} \\
\hline & & \multicolumn{4}{|c|}{ Levovil } & \multicolumn{4}{|c|}{ Cervil } & & \\
\hline & & \multicolumn{2}{|c|}{$14 D P A$} & \multicolumn{2}{|r|}{$R R$} & \multicolumn{2}{|c|}{$14 D P A$} & \multicolumn{2}{|r|}{$R R$} & & \\
\hline & & $\mathrm{Na}$ & $\mathrm{Ca}+\mathrm{Na}$ & $\mathrm{Na}$ & $\mathrm{Ca}+\mathrm{Na}$ & $\mathrm{Na}$ & $\mathrm{Ca}+\mathrm{Na}$ & $\mathrm{Na}$ & $\mathrm{Ca}+\mathrm{Na}$ & Levovil & Cervil \\
\hline FC1 & $50 S$ ribosomal protein L12-1a & - & * & - & - & * & * & * & * & - & - \\
\hline FC2 & ATP synthase D chain & - & * & - & * & - & * & - & * & - & - \\
\hline FC3 & ATP synthase delta chain & - & * & - & * & - & * & - & * & * & * \\
\hline FC4 & $\begin{array}{l}\text { S-adenosylmethionine } \\
\text { synthetase } 2\end{array}$ & - & * & - & * & - & * & - & * & - & - \\
\hline FC5 & Actin, complete & - & * & - & * & - & * & - & * & + & + \\
\hline FC6 & $\begin{array}{l}\text { Isocitrate dehydrogenase } \\
(\mathrm{NADP}+)\end{array}$ & - & * & * & * & - & * & - & * & - & - \\
\hline FC7 & $\begin{array}{l}\text { Isocitrate dehydrogenase } \\
(\mathrm{NADP}+)\end{array}$ & - & * & - & * & - & * & - & * & + & + \\
\hline FC8 & Glutathione peroxidase & - & * & - & * & - & * & - & * & - & - \\
\hline FC9 & Adenosine kinase 2 & - & * & - & * & - & * & * & * & - & - \\
\hline FC10 & Alcohol dehydrogenase & - & * & + & + & - & * & - & * & + & + \\
\hline FC11 & Polygalacturonase & * & * & * & + & - & * & - & * & + & + \\
\hline $\mathrm{FC} 12$ & Endochitinase & * & - & - & - & * & * & * & * & + & + \\
\hline FC13 & $\begin{array}{l}\text { Superoxide dismutase [Mn], } \\
\text { mitochondrial }\end{array}$ & - & * & - & * & - & * & - & * & + & + \\
\hline FC14 & $\begin{array}{l}\text { Protein disulfide-isomerase } \\
\text { precursor }\end{array}$ & - & * & - & * & - & * & * & * & - & - \\
\hline FC15 & $\begin{array}{l}\text { Protein disulfide-isomerase } \\
\text { precursor }\end{array}$ & * & * & * & * & - & * & * & * & - & - \\
\hline FC16 & Fructokinase 3, complete & - & * & * & * & - & * & * & * & + & + \\
\hline FC17 & HSP22 & + & * & + & + & + & * & - & * & + & + \\
\hline FC18 & $\begin{array}{l}\text { Lactoylglutathione lyase, allele } \\
\text { cervil }\end{array}$ & * & * & - & - & - & * & * & * & + & + \\
\hline FC19 & Acireductone dioxygenase & * & * & * & * & * & * & - & * & + & + \\
\hline FC20 & $\begin{array}{l}\text { Lactoylglutathione lyase, allele } \\
\text { levovil }\end{array}$ & - & * & * & * & * & * & * & * & * & * \\
\hline FC21 & Beta-D-xylosidase, LEXYL2 & - & - & - & - & * & * & * & * & + & + \\
\hline FC22 & $\begin{array}{l}\text { Beta-fructofuranosidase / } \\
\text { BFRUCT3 }\end{array}$ & * & * & * & * & * & * & - & - & + & + \\
\hline FC23 & SN-2 protein & * & * & - & + & * & * & - & * & + & + \\
\hline $\mathrm{FC} 24$ & $\begin{array}{l}\text { Universal stress protein (USP) } \\
\text { family protein }\end{array}$ & + & * & * & * & + & * & - & * & + & + \\
\hline FC25 & $\begin{array}{l}\text { Peptide methionine sulfoxide } \\
\text { reductase }\end{array}$ & + & * & - & * & * & * & - & * & + & + \\
\hline FC26 & $\begin{array}{l}\text { Peptide methionine sulfoxide } \\
\text { reductase }\end{array}$ & * & * & - & * & * & * & + & * & + & + \\
\hline FC27 & $\begin{array}{l}\text { Cytochrome b5 domain- } \\
\text { containing protein }\end{array}$ & + & * & + & * & + & * & + & * & + & * \\
\hline FC28 & $\begin{array}{l}\text { Chloroplast inorganic } \\
\text { pyrophosphatase }\end{array}$ & + & * & * & * & + & * & + & * & - & - \\
\hline FC29 & Enolase & + & * & + & * & + & * & + & * & - & - \\
\hline FC30 & $\begin{array}{l}\text { Oxidoreductase, zinc-binding } \\
\text { dehydrogenase family protein }\end{array}$ & + & * & + & * & + & * & + & * & * & * \\
\hline FC31 & $20 \mathrm{kDa}$ chaperonin, chloroplast & + & * & * & * & + & * & + & * & - & - \\
\hline FC32 & $\begin{array}{l}\text { Small heat shock protein-like } \\
\text { (HSP26.5-P) }\end{array}$ & + & * & * & * & + & * & + & * & + & + \\
\hline FC33 & Annexin P34 & + & * & + & + & + & * & + & * & * & * \\
\hline FC34 & $\begin{array}{l}17.8 \mathrm{kDa} \text { class I heat shock } \\
\text { protein }\end{array}$ & + & * & + & + & + & * & + & * & + & + \\
\hline FC35 & $\begin{array}{l}\text { Nascent polypeptide associated } \\
\text { complex alpha chain protein }\end{array}$ & + & * & + & * & + & * & + & * & + & + \\
\hline FC36 & $\begin{array}{l}\text { Nascent polypeptide associated } \\
\text { complex alpha chain protein }\end{array}$ & + & * & + & * & + & * & + & * & + & * \\
\hline
\end{tabular}


TABle 3. (CONTINUED)

\begin{tabular}{|c|c|c|c|c|c|c|c|c|c|c|c|}
\hline \multirow[b]{4}{*}{ Spot ID } & \multirow[b]{4}{*}{ Protein identification } & \multicolumn{8}{|c|}{ Salt effect (compared to control) } & \multirow{3}{*}{\multicolumn{2}{|c|}{$\begin{array}{c}\text { Fruit stage effect } \\
\text { (transition from mature } \\
\text { green to RR stage) }\end{array}$}} \\
\hline & & \multicolumn{4}{|c|}{ Levovil } & \multicolumn{4}{|c|}{ Cervil } & & \\
\hline & & \multicolumn{2}{|c|}{$14 D P A$} & \multicolumn{2}{|r|}{$R R$} & \multicolumn{2}{|c|}{$14 D P A$} & \multicolumn{2}{|r|}{$R R$} & & \\
\hline & & $\mathrm{Na}$ & $\mathrm{Ca}+\mathrm{Na}$ & $\mathrm{Na}$ & $\mathrm{Ca}+\mathrm{Na}$ & $\mathrm{Na}$ & $\mathrm{Ca}+\mathrm{Na}$ & $\mathrm{Na}$ & $\mathrm{Ca}+\mathrm{Na}$ & Levovil & Cervil \\
\hline FC37 & ACC oxidase 1 & * & * & + & * & * & * & + & * & * & * \\
\hline FC38 & $\begin{array}{l}\text { 1-aminocyclopropane-1- } \\
\text { carboxylate oxidase homolog } \\
\text { (Protein E8) }\end{array}$ & + & * & + & * & + & * & + & * & + & + \\
\hline FC39 & $\begin{array}{l}\text { Putative nucleic acid binding } \\
\text { protein }\end{array}$ & + & * & + & * & * & * & + & * & $*$ & * \\
\hline FC40 & Glycine-rich protein & + & * & + & * & + & * & + & * & + & + \\
\hline FC41 & Glycine-rich protein & + & * & + & * & + & * & + & * & + & + \\
\hline FC42 & Peroxidase & + & * & + & * & + & * & + & * & + & + \\
\hline FC43 & No hit & + & * & + & * & + & * & + & - & * & + \\
\hline FC44 & Cysteine proteinase 3 precursor & * & * & * & * & * & * & * & * & + & + \\
\hline FC45 & $\begin{array}{l}\text { Similar to outer membrane } \\
\text { lipoprotein-like (lipocalin) }\end{array}$ & * & * & * & * & * & * & * & * & + & + \\
\hline FC46 & $\begin{array}{l}\text { Putative F1F0-ATPase inhibitor } \\
\text { protein }\end{array}$ & * & * & * & * & * & * & + & * & + & + \\
\hline FC47 & $\begin{array}{l}\text { Acid beta-fructofuranosidase } \\
\text { precursor }\end{array}$ & * & * & + & * & * & * & * & - & + & + \\
\hline FC48 & $\begin{array}{l}\text { Acid beta-fructofuranosidase } \\
\text { precursor }\end{array}$ & * & * & * & * & * & * & * & * & + & + \\
\hline FC49 & Elicitor-inducible protein EIG-J7 & * & * & * & * & * & * & * & * & + & + \\
\hline FC50 & $\begin{array}{l}\text { Chloroplast small heat shock } \\
\text { protein class I }\end{array}$ & + & * & * & * & * & * & + & * & + & + \\
\hline FC51 & $\begin{array}{l}\text { Glucan endo-1,3-beta-D- } \\
\text { glucosidase precursor }\end{array}$ & * & * & * & * & * & * & * & * & * & + \\
\hline FC52 & Protein AT3g04780 & * & * & * & * & * & $*$ & * & * & $*$ & * \\
\hline FC53 & $\begin{array}{l}\text { Protein At2g37660, chloroplast } \\
\text { precursor }\end{array}$ & * & * & * & * & * & * & * & * & * & * \\
\hline
\end{tabular}

$(-)$ indicates the downregulation of protein, $(+)$ indicates the upregulation of protein, and $\left(^{*}\right)$ nonsignificant effect.

The largest part of spots linked to stress defense (actin, spot 5; SN-2 protein, spot 23; universal stress protein, spot 24; cysteine proteinase, spot 44; and elicitor-inducible protein EIG-J7, spot 49) and to cell wall-related (glycine-rich protein; spots 40 and 41) were mainly increased in both genotypes at RR compared to mature green fruit stage. It was formerly reported that these proteins linked to stress defense were expressed in tomato root (Manaa et al., 2011) and in fruits through ripening (Drake et al., 1996; Faurobert et al., 2007).

\section{Fruit pericarp proteome exhibited relative abundance variations under salt treatment}

Our previous proteomic analysis on tomato seedlings (Manaa et al., 2011) demonstrated that identification of proteins, which are differentially expressed due to salt stress, is an important step in understanding the mechanisms underlying stress response and adaptation at the first development stage. However in the present work, comparative proteomic analysis was used to investigate the changes of protein profiles in Cervil or Levovil pericarp under various salt treatments (Control, $\mathrm{Na}$, or $\mathrm{Ca}+\mathrm{Na}$ ) and various fruit stages (14 DPA and RR). Representative 2D gel maps for different conditions are shown in Supplementary Figure S1. Examination of data revealed a total of 43 spots that showed reproducible differen- tial expression between different experimental conditions but 10 spots showed any variation (Table 3 ). In fact, 24 spots were downregulated and 19 spots were upregulated under salt treatment ( $\mathrm{Na}$ alone), without any effect under $(\mathrm{Ca}+\mathrm{Na})$ treatment, except 3 spots $(12,21$, and 22) that were decreased with salinity (both $\mathrm{Ca}+\mathrm{Na}$ and $\mathrm{Na}$ treatments). About 19 spots exhibited either up- or downregulation with an interaction effect of different factors (fruit stage, genotype, and salt treatment).

\section{Proteins associated with energy, carbon metabolism, and protein synthesis}

Under salt treatment conditions, abundance of fruit pericarp proteins was affected and the basic metabolisms were disturbed. Our proteomic analysis indicated that the changes in relative abundance of various proteins that were involved in the energy and carbon metabolism were identified as the NAD-dependent isocitrate dehydrogenase (spots 6 and 7), fructokinase (spot 16), ATP synthase (spots 2 and 3), and adenosine kinase (spot 9). All these proteins showed a decrease in relative abundance under salt treatment $(\mathrm{Na})$ in Cervil and Levovil genotypes, whatever the fruit stage. On the other hand, two other spots: $\beta$-D-xylosidase (spot 21) and $\beta$ fructofuranosidase (spot 22), showed a salt treatment effect 
that might be correlated to genotype and fruit stage development. These two proteins were increased at RR fruit stage but decreased under salt treatments $(\mathrm{Na}$ alone or $\mathrm{Ca}+\mathrm{Na}$, respectively) for the two tested genotypes.

NAD-dependent isocitrate dehydrogenase (NADP-IDH) is a critical enzyme of the tricarboxylic acid cycle that converts malate and NAD into oxaloacetate and NADH (Chen and Gadal, 1990). However, NADP-IDH has been considered to be a key step in the generation of 2-oxoglutarate for ammonium assimilation and amino acid biosynthesis in higher plants. Therefore, the reduced activity of NADP-IDH might only reflect a general reduction in organic acid metabolism in the mitochondria during fruit growth (Sadka et al., 2000).

Fructokinase may play a role in regulation of energy metabolism, possibly by providing fructose-6-phosphate for glycolysis or through conversion to UDP-glucose (UDPG) to support biosynthesis of cell wall material (Karni and Aloni, 2002). Fructose-6-phosphate is a major substrate for many sugar metabolic pathways including glycolysis, starch biosynthesis, and the oxidative pentose pathway (Dai et al., 2002). Under salt stress, by inhibiting photosynthesis, the amount of fructose-6-phosphate decreased through the decrease in photosynthetic sucrose. One of the important outputs of this study is the decrease in fructokinase, presumably as a result of negative feedback caused by a decrease in the amount of fructose-6-phosphate during fruit development under salt treatment $(\mathrm{Na})$.

Previous studies demonstrated that modifications of the cell wall during ripening tomato fruit are mediated by cell walldegrading enzymes such as $\beta$-D-xylosidase. The major activity of $\beta$-xylosidase and the expression of its gene LeXYL2 exhibits high activity manifested during fruit development (Bewley et al., 2000). The activity of the enzyme increased during early fruit growth, before decreasing during later development and ripening (Itai et al., 2003). Also, acid $\beta$-fructo-furanosidase was found to be upregulated in gene expression in the breaker stage, downregulated in the subsequent turning and light red stages, and then once again upregulated in the red stage of ripening (Kok et al., 2008). These two proteins were decreased by salt treatments $(\mathrm{Na}$ alone and $\mathrm{Ca}+\mathrm{Na})$, indicating a negative effect of salinity on their expression during fruit development. This is a new hypothesis raised by our work.

Starch is the predominant storage form of photoassimilates during fruit development, and ripening is characterized by a decline in starch content, sucrose import, and accumulation of hexoses (Rocco et al., 2006). Starch biosynthesis requires PPi removal, a process that may take place within chloroplast by inorganic pyrophosphatase (spot 28), which was detected in the pericarp of both genotypes and exhibited increasing level under salt stress (Na alone) compared to control.

\section{Proteins associated with ripening process}

Different proteins that have been identified and have particular interest can be directly correlated to the ripening process, such as the ACC oxidase (spot 37) and ACC synthase (spot 38), S-adenosylmethionine synthetase 2, SAMS (spot 4), polygalacturonase (spot 11), and peptide methionine sulfoxide reductase (spots 25 and 26).

The ripening of fleshy fruits corresponds to a series of biochemical, physiological, and structural changes that make the fruit attractive to the consumer. Although these processes vary from one type of fruit to the next, fruits can be divided into two broad groups, known as climacteric and nonclimacteric (Biale, 1964). Categorization into one group or the other depends on whether a fruit exhibits a peak in respiration (McMurchie et al., 1972) and ethylene production during ripening. The sharp increase in climacteric ethylene production at the onset of ripening is considered as controlling the initiation of changes in color, aromas, texture, flavor, and other biochemical and physiological attributes. It is well documented (Yang and Hoffman, 1984) that the pathway of ethylene biosynthesis proceeds from methionine, through Sadenosylmethionine (SAM) and 1-ethaminocyclopropane-1carboxylic acid (ACC) to ethylene and that the two key enzymes are ACC synthase (ACS) and ACC oxidase (ACO, formely ethylene-forming enzyme, EFE). Also various studies confirm that SAMS catalyzes the conversion of ATP and Lmethionine into SAM. Evidence for the upregulation of this pathway during fruit ripening originally came from studies describing ACC accumulation and increases in ACO and ACS activities in a variety of climacteric fruits (Abeles et al., 1992).

Accordingly, our data indicate that ACC oxidase and ACC synthase levels are maximal at the RR stage in both genotypes and increased considerably under salt treatment $(\mathrm{Na})$ whatever the fruit stage. The relative abundance of SAMS increased at mature green fruit stage, then decreased at the RR stage in both genotypes. Polygalacturonase showed the greatest level of accumulation at the RR stage, especially in Cervil. Under salt treatment $(\mathrm{Na})$, a decreased abundance of these two proteins was observed compared to control. In contrast, two isoforms of the peptide methionine sulfoxide reductase were detected and which increased at the RR stage and more accumulated in Cervil genotype. In addition, they showed downregulation under $(\mathrm{Na})$ treatment whatever fruit development stage except spot 25 which was upregulated by salt stress during RR stage in the Cervil genotype. Our data confirm that salinity affects all of the ripening parameters independently. However, it is possible that salinity shortens the fruit life span and influences all of the ripening parameters.

Polygalacturonase (PG), ACC synthase, and ACC oxidase, which are related to the ripening process, are also upregulated during the breaker/turning and red stages of ripening (Giovannoni, 2001). Furthermore, this study described the regulation of a ripening protein E8 homolog in the red stage of ripening. A large increase in the breaker/turning versus green for polygalacturonase was detected in tomato fruit (Kok et al., 2008; Moore et al., 2002). The peptide corresponding to methionine sulfoxide reductase, also known as fruit-ripening protein E4, was found to be induced in the tomato regional ecotype during maturation (Rocco et al., 2006). Other proteomic results confirmed that SAMS was involved in tolerance to abiotic stresses such as wounding (Kim et al., 1994), salinity stress (Manaa et al., 2011), water stress (Vicente et al., 2009), drought stress (Gong et al., 2010), and heat shock (Süle et al., 2004).

\section{Proteins associated with stress and defense}

Salinity stress is associated with an enhanced risk of improper protein folding and denaturation of several intracellular protein and membrane complexes. It has long been well 
known that salt stress leads to an increase of accumulation of several proteins with protective functions, especially several members of large family of heat-shock-proteins (HSPs) (Wang et al., 2008). In tomato, small HSPs have already been shown to be involved in fruit developmental processes (Neta-Sharir et al., 2005). Our study picked out four HSP (spots 17, 32, 34, and 50) increased during RR as compared to mature green stage in Cervil and Levovil genotypes. The greatest level of accumulation was detected in Cervil genotype under control condition during two fruit stages. Salt treatment $(\mathrm{Na})$ led to increase protein relative abundance of HSP, except chloroplast sHSP (spot 50), which showed increasing levels in Cervil genotype irrigated with salt treatment (Na alone) at RR fruit stage. Previous data indicate upregulation of different HSP spots during development and ripening of tomato fruit (Faurobert et al., 2007; NetaSharir et al., 2005; Rocco et al., 2006). HSP proteins are among the most well-known stress-related proteins in plants that have been induced under several types of stress condition such as heat, osmotic, and salt stress (Kosová et al., 2011; Zhang et al., 2012). These proteins can act as a chaperone that helps in correct folding of proteins and protects them from denaturing under stress conditions. Induction of these proteins in this study is one of the mechanisms which may confer salt tolerance genotype.

Some other proteins that are involved in cell wall biogenesis are plant's first line of defense against salt stress. Among these, glycine-rich protein (spots 40 and 41) was increased at RR stage and more induced under salt treatment $(\mathrm{Na})$ in both genotypes. Relative abundance of annexin P34 (spot 33) was unmodified during fruit development but showed a remarkable increase in Cervil genotype under salt condition (Na) as compared to control.

Annexins are a multigene, multifunctional family of soluble proteins and play important roles in various cellular processes, including membrane trafficking and organization, regulation of ion channel activity, and phospholipid metabolism (Clark et al., 2001; Seals et al., 1997). Annexins are characterized by their ability to bind phospholipids in a $\mathrm{Ca}^{2+}$. dependent manner. The functions of annexins have been determined in various plant species. In tobacco, annexin P34 is vacuole specific and involved in cell expansion (Seals et al., 1997). In tomato, annexin P34 expression shows a close relationship among fruit ripening stages (Faurobert et al., 2007). In strawberry and bell pepper, an annexin mRNA was upregulated during fruit ripening (Proust et al., 1996). Moreover, protein similar to Universal Stress Protein was detected in our gel (spot 24), which was increased during RR fruit development and decreased under salt stress $(\mathrm{Na})$ whatever the genotype or fruit ripening stage. Our data are in agreement with previous studies (Faurobert et al., 2007).

Two other proteins that could be included in stress defense were identified as cysteine proteinase (spot 44, Avrova et al., 1996) and elicitor-inducible protein EIG-J7 (spot 49; Takemoto et al., 2001), which exhibited the greatest level of accumulation at RR stage and no effect of salt stress was detected. The last spot is actin (spot 5), which could be associated to cell wall defense, was more intense during RR stage than green stage in both genotypes. However, actin exhibited downregulation under salt stress $(\mathrm{Na})$. There are fewer data concerning interaction between salt stress effect and ripening process for actin cell content (Wang et al., 2011).
On the other hand, endochitinase (spot 12), known as cell wall associated contigs and antifungal protein, was exceptionally detected in Levovil at RR stage and negatively affected by salt stress $(\mathrm{Na}$ or $\mathrm{Ca}+\mathrm{Na}$ ). Previously, this protein has been reported to have altered expression in long-term cold stored fruits (Vizoso et al., 2009) but in our studies, expression of this protein illustrates specific defense response in Cervil.

\section{Proteins associated with oxidative stress}

Salt stress leads to the overproduction of reactive oxygen species (ROS) in plants that are highly reactive and toxic and cause damage to proteins, membrane lipids, carbohydrates, and nucleic acids, which ultimately results in oxidative stress (Apel and Hirt, 2004; Gill and Tuteja, 2010). Antioxidants modulate the steady-state concentrations of ROS, avoiding their potential cytotoxicity while allowing them to function as signal molecules (Mittler et al., 2004). Antioxidant enzymes include superoxide dismutase (SOD), peroxidase, and glutathione peroxidases (GPX) (Gill and Tuteja, 2010; Mittler et al., 2004). Most extensive studies on the role of ROS and antioxidants in fruit development and maturation (ripening) have been conducted on climacteric fruits such as tomato Lycopersicon esculentum (Gautier et al., 2009; Rocco et al., 2006). In the present study, such proteins (spots 8,13,42) were detected in our experiment, protected plant cells from oxidative damage by scavenging of ROS (Apel and Hirt, 2004; Bhushan et al., 2007; Gill and Tuteja, 2010). Peroxidase (spot 42) with the greatest level of accumulation was detected in RR fruit with Cervil exhibiting higher levels than Levovil. Peroxidase increased with $\mathrm{Na}$ treatment in Cervil and Levovil mostly at the RR stage. Mitochondrial superoxide dismutase (MnSOD; spot 13) exhibited a significant increase in RR fruit as compared to the green stage, mostly in Cervil genotype. In contrast, SOD exhibited a general decrease in intensity in both genotypes under salt stress $(\mathrm{Na})$ at whatever fruit stage. In agreement with our results, previous studies reported that SOD activity increased during late tomato ripening, whose changes were unrelated to cytosolic SOD mRNA levels (Rocco et al., 2006). Other authors also observed in cherry tomato a transient increase in the SOD from green to orange stage, followed by a decrease at the end of the ripening (Ahn et al., 2002). Indeed, Gautier et al. (2009) demonstrated that changes in enzymatic activities of antioxidants in tomato fruit were strongly dependent on the genotype and on the salinity treatment. They observed an increase in ascorbate peroxidase and SOD activities in response to salt treatment $(\mathrm{Na})$ with a strong variation among genotypes and fruit development stage. This suggests that the accumulation of SOD, especially in our study under saline conditions, no longer reflects the degree of tolerance or sensitivity of tomato genotypes. In a similar manner, glutathione peroxidase (spot 8) was detected in our experiment and was downregulated under $\mathrm{Na}$ treatment. These results suggest that during fruit ripening, efficient antioxidant system protects the tomato fruits against the damaging effect of progressive oxidative stress. However, oxidative damage occurs due to decreased activities of the ROS scavenging enzymes (Gill and Tuteja, 2010). According to previous studies (Gautier et al. 2009), increased Na content in fruit tissue may be responsible for increased oxidative parameters. 
Lactoylglutathione lyase (spots 18 and 20) were also identified as abundant proteins in Cervil and Levovil genotypes, respectively, and were upregulated from the green to the RR stage. The first one (spot 18) exhibited downregulation under $\mathrm{Na}$ treatment only at the green stage in Cervil. The second one (spot 20) which was Levovil specific, exhibited a slight increase in abundance level with salt treatment $(\mathrm{Na}$ or $\mathrm{Ca}+\mathrm{Na}$ ). It is worth noting that other proteins involved in oxidative process were identified as enolase (spot 29) and nascent polypeptide associated complex alpha chain protein (spots 35 and 36). All of them were increased at RR compared to the green stage whatever the genotype and exhibited an increase in level under salt stress (Na). As established in our previous data (Manaa et al. 2011), the distant phylogenetic between Cervil (a cerasiforme type) and Levovil (a classical largefruited S. lycopersicum) may explain the fruit proteome variation among these two genotypes under salt treatments (Ranc et al., 2008).

\section{Miscellaneous}

Different proteins that are not classified in the above categories have also been identified. Among them, some are of particular interest as the outer membrane lipoprotein (spot 45) belongs to the lipocalin family, a class of proteins binding small hydrophobic molecules, with a function well characterized in animals (Flower, 1996) but much less in plants. In our experiment, protein relative abundance increased at $R R$ as compared to mature green stage. Nevertheless, salt treatments $(\mathrm{Na}$ or $\mathrm{Ca}+\mathrm{Na}$ ) have no significant effect on protein accumulation. Our quantitative analysis seems to parallel well with some studies, since an upregulation of the outermembrane lipoprotein was observed during fruit maturation from green to red stage in two tomato ecotypes (Rocco et al., 2006).

Proteins associated to biotic stress as pathogenesis (cytochromes b5, spot 27 , and putative nucleic acid binding protein, spot 39) were identified and exhibited an increased level at the RR stage. These proteins were also increased under salt treatment (Na) in Cervil and Levovil. Cytochromes b5 (spot 27) can be defined as electron transfer proteins. Cyt b5 possess a wide range of properties and function in a large number of different redox processes (Bagnaresi et al., 2000). Putative nucleic acid binding protein plays an essential role in modification of plasmodesmata (Franks et al., 2008), but there are fewer data concerning its effect on ripening process and salt stress.

\section{Calcium application mitigates damaging effects of salt stress on fruit proteome}

The greatest effect observed in our report was the mitigating effect of exogenous calcium on metabolic activities of fruit tomato restrained by salinity. As discussed above, 24 spots were downregulated and 19 spots were upregulated under salt treatment $(\mathrm{Na})$. Nevertheless, a combination of $\mathrm{Ca}+\mathrm{Na}$ has similar effects on protein abundance as compared to control treatment (Table 3). Thus, exogenous calcium seems to induce adaptation to salinity in tomato fruit through the activation of the enzymes involved in energy and carbohydrate metabolism. In fact, relative abundance of two ATP synthase (spots 2 and 3) and putative F1F0-ATPase (spot 46) were remarkably decreased under salt treatment $(\mathrm{Na})$ in
Cervil and Levovil genotypes at the RR and green stages, but any variation was observed with moderate salinity $(\mathrm{Ca}+\mathrm{Na})$. ATP synthases (ATPases) are membrane-bound enzyme complexes/ion transporters that combine ATP synthesis and/or hydrolysis with the transport of protons through the membrane, playing a key role in biological energy metabolism. ATPases differ in respect to function (ATP synthesis and/or hydrolysis), structure (F-, V- and A-ATPases contain rotary motors), and in the type of ions they transport (Cross and Müller, 2004; Rappas et al., 2004). F1-ATPases in mitochondria, chloroplasts, and bacterial plasma membranes are the prime producers of ATP, using the proton gradient generated by oxidative phosphorylation (mitochondria) or photosynthesis (chloroplasts). Mitochondrial $\mathrm{Ca}^{2+}$ accumulation triggers activation of mitochondrial metabolism, which increases ATP synthesis in mitochondria and ATP levels in cytosol (Jouaville et al., 1999) In addition, the reduced activity of NAD-dependent isocitrate dehydrogenase (spots 6 and 7) under salt treatment $(\mathrm{Na})$ in Cervil and Levovil genotypes during fruit growth, is restored under $(\mathrm{Ca}+\mathrm{Na})$ treatment. This phenomenon suggests that salinity dramatically inhibits energy metabolism in tomato fruit and in the case of these two ATPases, calcium can completely restore them to control levels.

In the present study, perturbations of enzymes implicated in starch activity such as inorganic pyrophosphatase (spot 28) and fructokinase (spot 16) under salt stress (Na) were reestablished with calcium application $(\mathrm{Ca}+\mathrm{Na})$. These observations provide a convenient explanation of the adaptive response of tomato to salinity, namely, that plants control their energy consumption by modulating the synthesis of storage substances such as starch (Gupta and Kaur, 2005). Therefore, calcium seems to improve carbohydrate metabolism and induces sugar signaling to enhance salt tolerance of tomato fruit.

In addition, the exogenous calcium could enhance the antioxidant enzyme activities, which in turn could reduce ROS accumulation and inhibit protein oxidative damage (He et al., 2012). Our data showed that proteins involved in oxidative process; peroxidase (spot 42; upregulated), SOD and glutathione peroxidase (spot 8 and spot 13; downregulated) under salt stress $(\mathrm{Na})$, were unmodified by adding $\mathrm{Ca}+\mathrm{Na}$ as compared to control treatment for the two genotypes, particularly during the RR stage. Thus, exogenous calcium can enhance the activities of ROS-scavenging enzymes to defend against the damage caused by ROS, which would suppress the salt stress effects.

Preceding studies showed that $\mathrm{Na}$ treatment strongly increased oxidative stress parameters $\left(\left[\mathrm{H}_{2} \mathrm{O}_{2}\right]\right.$ or $\left.[\mathrm{MDA}]\right)$ as compared to the $\mathrm{Ca}+\mathrm{Na}$ treatment, which triggered a lower or no increase in these parameters (Gautier et al., 2009). They demonstrated that combination of $\mathrm{Ca}+\mathrm{Na}$ compared to $\mathrm{Na}$ treatment led to a lower stress that may be due to the lower $\mathrm{Na}$ concentration within fruit.

For the most part, glutathione acts to stimulate calcium release into the cytosol, an effect that appears to depend on total glutathione concentration. As previously discussed in depth (Gill and Tuteja, 2010), the accumulation of glutathione occurs in response to various stresses and the attendant release of calcium may mean that glutathione accumulation is equally as important in signal transduction as in chemical defense against reactive oxygen. By triggering the activation 
of calcium-dependent protein kinases, increases in glutathione concentration may participate in early signal transduction events and function in the integration of multiple abiotic stimuli (Gomez et al., 2004).

\section{Conclusion}

The present study underlines profound changes in proteome composition among compared genotypes, cultivated at two fruit ripening stages under various salt conditions ( $\mathrm{Na}$ or $\mathrm{Ca}+\mathrm{Na}$ ). In fact, the ripening stage was the largest source of variation between samples and genotypes. Our findings reveal a large variation on fruit proteome among the two genotypes that can be correlated with salt treatment or/and fruit ripening stage. The greatest effect observed in our report was the positive effect of calcium that can be greatly used to enhance salt tolerance of tomato plants. Thus, more efforts to investigate protein trafficking as well as calcium-signal transduction and molecular signaling may contribute to greater comprehension of the full metabolic picture displayed during fruit development and ripening under salt stress conditions.

\section{Acknowledgments}

The authors acknowledge the Ministry of Higher Education and Scientific Research of Tunisia for financial support. Many thanks to Hélène Gautier for her help in fruit collect and Karine Leyre for technical assistance. We also thank Chokri Hafsi and Jeff Leung for critical reading of the manuscript.

\section{Author Disclosure Statement}

The authors declare that no conflicting financial interests exist.

\section{References}

Abeles F, Morgan P, and Saltveit JM. (1992). Ethylene in Plant Biology, 2nd edn. San Diego: Academic Press.

Adams P. (1991). Effect of increasing the salinity of the nutrient solution with major nutrients or sodium chloride on the yield quality and composition of tomato grown in rockwool. J Hort Sci 66, 201-207.

Adams-Phillips L, Barry C, and Giovannoni J. (2004). Signal transduction systems regulating fruit ripening. Trends Plant Sci 9, 331-338.

Ahn T, Schofield A, and Gopinadhan P. (2002). Changes in antioxidant enzyme activities during tomato fruit development. Physiol Mol Biol Plant 8, 241-249.

Ahsan N, Lee DG, Lee SH, Lee KW, Bahk J, and Lee BH. (2007). A proteomic screen and identification of waterloggingregulated proteins in tomato roots. Plant and Soil 295, 37-51.

Ahsan N, Renaut J, and Komatsu S. (2009). Recent developments in the application of proteomics to the analysis of plant responses to heavy metals. Proteomics 9, 2602-2621.

Alvarez S, Marsh EL, Schroeder SG, and Schachtman DP. (2008). Metabolomic and proteomic changes in the xylem sap of maize under drought. Plant Cell Environ 31, 325-340.

Apel K, and Hirt H. (2004). Reactive oxygen species: Metabolism, oxidative stress, and signal transduction. Annu Rev Plant Biol 55, 373-399.

Avrova AO, Stewart HE, De Jong W, Heilbronn J, Lyon GD, and Birch PR. (1999). A cysteine protease gene is expressed early in resistant potato interactions with Phytophthora infestans. Mol Plant Microbe Interact 12, 1114-1119.

Bagnaresi P, Mazars-Marty D, Pupillo P, Marty F, and Briat JF. (2000). Tonoplast subcellular localization of maize cytochrome b5 reductases. Plant J 24, 645-654.

Bewley JD, Banik M, Bourgault R, Feurtado JA, Toorop P, and Hilhorst HW. (2000). Endo-mannanase activity increases in the skin and outer pericarp of tomato fruits during ripening. J Exp Bot 51, 529-538.

Bhushan D, Pandey A, Choudhary MK, Datta A, Chakraborty S, and Chakraborty N. (2007). Comparative proteomics analysis of differentially expressed proteins in chickpea extracellular matrix during dehydration stress. Mol Cell Proteomics 6, 1868-1884.

Biale J. (1964). Growth, maturation and senescence in fruits. Science 146, 880-888.

Bush DS. (1995). Calcium regulation in plant cells and its role in signaling. Annu Rev Plant Physiol Plant Mol Biol 46, 95-122.

Carrari F, Baxter C, Usadel Br, et al. (2006). Integrated analysis of metabolite and transcript levels reveals the metabolic shifts that underlie tomato fruit development and highlight regulatory aspects of metabolic network behavior. Plant Physiol 142, 1380-1396.

Carrari F, and Fernie AR. (2006). Metabolic regulation underlying tomato fruit development. J Exp Bot 57, 1883-1897.

Chen R, and Gadal P. (1990). Structure, functions and regulation of NAD and NADP-dependent isocitrate dehydrogenases in higher plants and in other organisms. Plant Physiol Biochem 28, 411-427.

Chung MY, Vrebalov J, Alba R, et al. (2010). A tomato (Solanum lycopersicum) APETALA2/ERF gene, SlAP2a, is a negative regulator of fruit ripening. Plant J 64, 936-947.

Clark GB, Sessions A, Eastburn DJ, and Roux SJ. (2001). Differential expression of members of the annexin multigene Family in Arabidopsis. Plant Physiol 126, 1072-1084.

Cross RL, and Müller V. (2004). The evolution of A-, F-, and Vtype ATP synthases and ATPases: Reversals in function and changes in the $\mathrm{H}^{+}$/ATP coupling ratio. FEBS Lett 576, 1-4.

D'Amico ML, Izzo R, Tognoni F, Pardossi A, and Navari-Izzo F. (2003). Application of diluted sea water to soilless culture of tomato (Lycopersicon esculentum Mill.): Effects on plant growth, yield, fruit quality and antioxidant capacity. Food Agric Environ 1, 112-116.

Dai N, German MA, Matsevitz T, et al. (2002). LeFRK2, the gene encoding the major fructokinase in tomato fruits, is not required for starch biosynthesis in developing fruits. Plant Sci $162,423-430$.

De Pascale S, Maggio A, Fogliano V, Ambrosino P, and Ritieni A. (2001). Irrigation with saline water improves carotenoids content and antioxidant activity of tomato. J Hort Sci Bio 76, 447-453.

Dorais M, Papadopoulos AP, and Gosselin A. (2001). Influence of electric conductivity management on greenhouse tomato yield and fruit quality. Agronomie 21, 367-383.

Drake R, John I, Farrell A, Cooper W, Schuch W, and Grierson D. (1996). Isolation and analysis of cDNAs encoding tomato cysteine proteases expressed during leaf senescence. Plant Mol Biol 30, 755-767.

Ehret DL, Redmann RE, Harvey BL, and Cipywnyk A. (1990). Salinity-induced calcium deficiencies in wheat and barley. Plant Soil 128, 143-151.

Faurobert M, Mihr C, Bertin N, et al. (2007). Major proteome variations associated with cherry tomato pericarp development and ripening. Plant Physiol 143, 1327-1346.

Faurobert M, Pelpoir E, and Chaïb J. (2006). Phenol extraction of proteins for proteomic studies of recalcitrant plant tissues. ed, 
Plant Proteomics. Methods and Protocols, vol. 355, Humana Press, Totowa, NJ, pp 9-14.

Fei Z, Tang X, Alba RM, et al. (2004). Comprehensive EST analysis of tomato and comparative genomics of fruit ripening. Plant J 40, 47-59.

Flower D. (1996). The lipocalin family: Structure and function. Biochem J 318, 1-14.

Franks A, Mark-Byrne GL, Maxwell DJ, and O'Gara F. (2008). A putative RNA-binding protein has a role in virulence in Ralstonia solanacearum GMI1000. Mol Plant Pathol 9, 67-72.

Gao F, Zhou Y, Zhu W, Li X, Fan L, and Zhang G. (2009). Proteomic analysis of cold stress-responsive proteins in Thellungiella rosette leaves. Planta 230, 1033-1046.

Gautier H, Lopez-Lauri F, Massot C, et al. (2009). Impact of ripening and salinity on tomato fruit ascorbate content and enzymatic activities related to ascorbate recycling. Fun Plant Sci Bio 3, 66-75.

Gill SS, and Tuteja N. (2010). Reactive oxygen species and antioxidant machinery in abiotic stress tolerance in crop plants. Plant Physiol Biochem 48, 909-930.

Giovannoni J. (2001). Molecular biology of fruit maturation and ripening. Annu Rev Plant Physiol Plant Mol Biol 52, 725-749.

Giovannoni JJ. (2004). Genetic regulation of fruit development and ripening. Plant Cell 16, 170-180.

Giovannoni JJ. (2007). Fruit ripening mutants yield insights into ripening control. Curr Opin Plant Biol 10, 283-289.

Gomez LD, Noctor G, Knight MR, and Foyer CH. (2004). Regulation of calcium signalling and gene expression by glutathione. J Exp Bot 55, 1851-1859.

Gong P, Zhang J, Li H, et al. (2010). Transcriptional profiles of drought-responsive genes in modulating transcription signal transduction, and biochemical pathways in tomato. J Exp Bot 61, 3563-3575.

Gupta A, and Kaur N. (2005). Sugar signalling and gene expression in relation to carbohydrate metabolism under abiotic stresses in plants. J Biosci 30, 761-776.

He L, Lu X, Tian J, et al. (2012). Proteomic analysis of the effects of exogenous calcium on hypoxic-responsive proteins in $\mathrm{cu}-$ cumber roots. Proteome Sci 10: 42.

Holmes P, Farquharson R, Hall PJ, and Rolfe BG. (2006). Proteomic analysis of root meristems and the effects of acetohydroxyacid synthase-inhibiting herbicides in the root of Medicago truncatula. J Proteome Res 5, 2309-2316.

Incerti A, Navari-Izzo F, Pardossi A, Mensuali A, and Izzo R. (2007). Effect of sea water on biochemical properties of fruit of tomato (Lycopersicon esculentum Mill.) genotypes differing for ethylene production. J Sci Food Agric 87, 2528-2537.

Itai A, Kotaki T, Tanabe K, Tamura F, Kawaguchi D, and Fukuda M. (2003). Rapid identification of 1-aminocyclopropane-1-carboxylate (ACC) synthase genotypes in cultivars of Japanese pear (Pyrus pyrifolia Nakai) using CAPS markers. Theor Appl Genet 106, 1266-1272.

Jiang Y, Yang B, Harris NS, and Deyholos MK. (2007). Comparative proteomic analysis of $\mathrm{NaCl}$ stress-responsive proteins in Arabidopsis roots. J Exp Bot 58, 3591-3607.

Jimenez A, Creissen G, Kular B, et al. (2002). Changes in oxidative processes and components of the antioxidant system during tomato fruit ripening. Planta 214, 751-758.

Jouaville LS, Pinton P, Bastianutto C, Rutter GA, and Rizzuto R. (1999). Regulation of mitochondrial ATP synthesis by calcium: Evidence for a long-term metabolic priming. Proc Natl Acad Sci USA 96, 13807-13812.

Karlova R, Rosin FM, Busscher-Lange J, et al. (2011). Transcriptome and metabolite profiling show that APETALA2a is a major regulator of tomato fruit ripening. Plant Cell 23, 923941.

Karni L, and Aloni B. (2002). Fructokinase and hexokinase from pollen grains of bell pepper (Capsicum annuum L.): Possible role in pollen germination under conditions of high temperature and $\mathrm{CO}_{2}$ enrichment. Ann Bot 90, 607-612.

Kaspar S, Matros A, and Mock HP. (2010). Proteome and flavonoid analysis reveals distinct responses of epidermal tissue and whole leaves upon UV-B radiation of Barley (Hordeum vulgare L.) seedlings. J Proteome Res 9, 2402-2411.

Kaya C, Ak BE, and Higgs D. (2003). Response of salt-stressed strawberry plants to supplementary calcium nitrate and/or potassium nitrate. J Plant Nutr 26, 543-560.

Kim CS, Kwak JM, Nam HG, Kim KC, and Cho BH. (1994). Isolation and characterization of two cDNA clones that are rapidly induced during the wound response of Arabidopsis thaliana. Plant Cell Rep 13, 340-343.

Kok EJ, Lehesranta SJ, van Dijk JP, et al. (2008). Changes in gene and protein expression during tomato ripening. Consequences for the safety assessment of new crop plant varieties. Food Sci Technol Int 14, 503-518.

Kosová K, Vítámvás P, Prášil IT, and Renaut J. (2011). Plant proteome changes under abiotic stress. Contribution of proteomics studies to understanding plant stress response. J Proteomics 74, 1301-1322.

Lemaire-Chamley M, Petit J, Garcia V, et al. (2005). Changes in transcriptional profiles are associated with early fruit tissue specialization in tomato. Plant Physiol 139, 750-769.

Malho R, Kaloriti D, and Sousa E. (2006). Calcium and rhythms in plant cells. Biol Rhythm Res 37, 297-314.

Manaa A, Ben Ahmed H, Valot Bt, et al. (2011). Salt and genotype impact on plant physiology and root proteome variations in tomato. J Exp Bot 62, 2797-2813.

McMurchie EJ, McGlasson WM, and Eaks IL. (1972). Treatment of fruit with propylene gives information about the biogenesis of ethylene. Nature 237, 658-660.

Mittler R, Vanderauwera S, Gollery M, and Van Breusegem F. (2004). Reactive oxygen gene network of plants. Trends Plant Sci 9, 490-498.

Mohammadi P, Moieni A, and Komatsu S. (2012). Comparative proteome analysis of drought-sensitive and drought-tolerant rapeseed roots and their hybrid F1 line under drought stress. Amino Acids 43, 2137-2152.

Moore S, Vrebalov J, Payton P, and Giovannoni J. (2002). Use of genomics tools to isolate key ripening genes and analyse fruit maturation in tomato. J Exp Bot 53, 2023-2030.

Neta-Sharir I, Isaacson T, Lurie S, and Weiss D. (2005). Dual role for tomato heat shock protein 21: Protecting photosystem II from oxidative stress and promoting color changes during fruit maturation. Plant Cell 17, 1829-1838.

Page D, Gouble B, Valot B, et al. (2010). Protective proteins are differentially expressed in tomato genotypes differing for their tolerance to low-temperature storage. Planta 232, 483-500.

Plieth C. (2005). Calcium: Just another regulator in the machinery of life? Ann Bot 96, 1-8.

Proust Jz, Houlné G, Schantz ML, and Schantz R. (1996). Characterization and gene expression of an annexin during fruit development in Capsicum annuum. FEBS Lett 383, 208-212.

Ramagli LS, and Rodriguez LV. (1985). Quantitation of microgram amounts of protein in two-dimensional polyacrylamide gel electrophoresis sample buffer. Electrophoresis 6, 559-563.

Ramakrishna W, Deng Z, Ding CK, Handa AK, and Ozminkowski RH. (2003). A novel small heat shock protein gene, 
vis1, contributes to pectin depolymerization and juice viscosity in tomato fruit. Plant Physiol 131, 725-735.

Ranc N, Munos S, Santoni S, and Causse M. (2008). A clarified position for Solanum lycopersicum var. cerasiforme in the evolutionary history of tomatoes (solanaceae). BMC Plant Biol 8: 130.

Rappas M, Niwa H, and Zhang X. (2004). Mechanisms of ATPases-A multidisciplinary approach. Curr Protein Pept Sci 5, 89-105.

Rocco M, D'Ambrosio C, Arena S, Faurobert M, Scaloni A, and Marra M. (2006). Proteomic analysis of tomato fruits from two ecotypes during ripening. Proteomics 6, 3781-3791.

Rossignol M, Peltier JB, Mock HP, Matros A, Maldonado AM, and Jorrin JV. (2006). Plant proteome analysis: A 2004-2006 update. Proteomics 6, 5529-5548.

Sadka A, Artzi B, Cohen L, et al. (2000). Arsenite reduces acid content in citrus fruit, inhibits activity of citrate synthase but induces its gene expression. J Am Soc Hort Sci 125, 288-293.

Salekdeh GH, Siopongco J, Wade LJ, Ghareyazie B, and Bennett J. (2002). Proteomic analysis of rice leaves during drought stress and recovery. Proteomics 2, 1131-1145.

Seals DF, and Randall SK. (1997). A vacuole-associated annexin protein, VCaB42, correlates with the expansion of tobacco cells. Plant Physiol 115, 753-761.

Smith CJS, Watson CF, Morris PC, et al. (1990). Inheritance and effect on ripening of antisense polygalacturonase genes in transgenic tomatoes. Plant Mol Biol 14, 369-379.

Sobhanian H, Motamed N, Jazii FR, Nakamura T, and Komatsu S. (2010). Salt stress induced differential proteome and metabolome response in the shoots of Aeluropus lagopoides (Poaceae), a halophyte C4 plant. J Proteome Res 9, 2882-2897.

Song JY, and Roe JH. (2008). The role and regulation of Trxl, a cytosolic thioredoxin in Schizosaccharomyces pombe. J Microbiol $46,408-414$.

Süle A, Vanrobaeys F, Hajos G, Van Beeumen J, and Devreese B. (2004). Proteomic analysis of small heat shock protein isoforms in barley shoots. Phytochemistry 65, 1853-1863.

Takemoto D, Doke N, and Kawakita K. (2001). Characterization of elicitor-inducible tobacco genes isolated by differential hybridization. J Gen Plant Pathol 67, 89-96.
Trewavas JA, and Malhó R. (1998). $\mathrm{Ca}^{2+}$ signaling in plant cells: The big network! Curr Opin Plant Biol 1, 428-433.

Vicente AR, Manganaris GA, Sozzi GO, and Crisosto CH. (2009). Nutritional quality of fruits and vegetables. In: Florkowski, Shewfelt, Brueckner and Prussia (eds.), Postharvest Handling: A Systems Approach, 2ed. Oxford: Academic Press, Chapter 5, pp. 57-106.

Vierling E. (1991). The roles of heat shock proteins in plants. Annu Rev Plant Physiol Plant Mol Biol 42, 579-620.

Vizoso P, Meisel L, Tittarelli A, et al. (2009). Comparative EST transcript profiling of peach fruits under different post-harvest conditions reveals candidate genes associated with peach fruit quality. BMC Genomics 10: 423.

Wang C, Zhang LJ, and Huang RD. (2011). Cytoskeleton and plant salt stress tolerance. Plant Signal Behav 6, 29-31.

Wang MC, Peng ZY, Li CL, Li F, Liu C, and Xia GM. (2008). Proteomic analysis on a high salt tolerance introgression strain of Triticum aestivum/Thinopyrum ponticum. Proteomics 8, 14701489.

Yang SF, and Hoffman NE. (1984). Ethylene biosynthesis and its regulation in higher plants. Annu Rev Plant Physiol 35, 155-189.

Zhang H, Han B, Wang T, et al. (2012). Mechanisms of plant salt response: Insights from proteomics. J Proteome Res 11, 49-67.

Zou J, Liu C, and Chen X. (2011). Proteomics of rice in response to heat stress and advances in genetic engineering for heat tolerance in rice. Plant Cell Rep 30, 2155-2165.

Address correspondence to: Arafet Manaa Unité d'Ecophysiologie et Nutrition des Plantes Département de Biologie Faculté des Sciences de Tunis Université Tunis El Manar 2092 Tunisie

E-mail: manaaarafet@gmail.com 